\title{
Investigating different influential factors on capital structure of different sectors of industries listed in Tehran Stock Exchange
}

\author{
Zahra Houshmand Neghabi $^{\mathbf{a}^{*}}$ and Sudabeh Morshedian Rafiee ${ }^{\mathrm{b}}$
}

${ }^{a}$ Faculty member, Department of Commercial Management, Islamshahr Branch, Islamic Azad University (IAU), Iran

${ }^{b}$ Assist. Prof. \& Faculty Member, Department of Commercial Management, Islamshahr Branch, Islamic Azad University (IAU), Iran

\section{H R O N I C L E}

Article history:

Received July 2, 2012

Received in revised format

28 October 2012

Accepted 12 November 2012

Available online

November 172012

Keywords:

Capital structure

Tehran Stock Exchange

Profitability

\begin{abstract}
Capital structure plays an important role on market growth investigation. In this paper, we investigate the relationship between capital structure as dependent variable and seven independent variables including tax rate, firms' growth rate, fixed assets, firms' size, operating risk, profitability and industry type. The proposed study of this paper uses the financial information of 107 selected companies from 18 different industries listed on Tehran Stock Exchange over the period of 2004-2011 covering $40 \%$ of total number of companies listed in this stock exchange. We use ordinary least square technique to study the relationships. The results of the survey indicate that the there is a positive relationship between tax rate and firm's growth rate, and capital structure. The result of the survey also indicates there is a negative relationship between firm's profitability and capital structure. However, there is no evidence to believe that there was any relationship between fixed assets and capital structure. We have also concluded that there was a negative relationship between firm's profitability and capital structure but the results of our survey did not indicate that there was any difference between the mean of profitability in various sectors.
\end{abstract}

\section{Introduction}

Capital structure plays an important role on financial performance of the stock market and there are literally different works dedicated on the effects of various factors on it (Lahmiri, 2012). Azouzi, and Anis (2012), for instance, investigated the determinants of firms' investment introducing a behavioral perspective, which has received little investigation in corporate finance literature. They discussed that investment decisions were influenced not only by their fundamentals but also they depended on some other influencing factors. One factor was the biasness of any CEO to their investment, biasness depended on the cognition and emotions, because some leaders used them as heuristic for the investment decision instead of fundamentals. The study showed how CEO emotional bias

*Corresponding author. Tel: +98-912-3443139

E-mail addresses: z_houshmand_Neghabi@yahoo.com (Z. Houshmand Neghabi) 
(optimism, loss aversion and overconfidence) influenced the investment decisions. The paper used Bayesian Network Method to investigate this relationship. Emotional bias had been measured by means of a questionnaire comprising several items. As for the selected sample, it has been composed of some 100 Tunisian executives. The results revealed that the behavioral analysis of investment decision implies leader had affected by behavioral biases (optimism, loss aversion, and overconfidence) adjusts its investment choices based on their ability to assess alternatives (optimism and overconfidence) and risk perception (loss aversion) to generate of shareholder value and ensure its place at the head of the management team.

de Jong et al. (2008) analyzed the relative importance of firm-specific and country-specific items in the leverage choice of firms from 42 different countries around the world. Their investigation yielded two new results. First, they reported that firm-specific determinants of leverage differ across various countries, while prior studies implicitly had assumed equal effects of these determinants. Second, they demonstrated that there was an indirect effect because country-specific factors also impacted the roles of firm-specific determinants of leverage. Delcoure (2007) performed an investigation to find out whether capital structure determinants in emerging Central and Eastern European (CEE) countries support traditional capital structure theory developed to explain western economies. The study reported that companies followed the modified "pecking order.” The factors, which influence firms' leverage decisions were the differences and financial constraints of banking systems, disparity in legal systems governing firms' operations, shareholders, and bondholders rights protection, corporate governance and sophistication of equity and bond markets.

Singh and Nejadmalayeri (2004) examined the relationship between financial structure, international diversification and their individual and interactive implications for the combined debt and equity expenditure of capital for some French corporation. They reported that the degree of international diversification positively associated with higher total and long-term debt ratios. The survey also recommended a non-linear inverted U-shape relationship between the degree of international diversification and short-term debt financing. They found that internationally diversified firms supported higher level of debt financing, which directly results in reduction of overall cost of capital despite higher equity risk. They also reported that even after controlling for the impacts of risk, firm size, managerial agency costs, the degree and composition of debt financing, equity and asset structure, higher degree of international diversification resulted in lower overall—combined debt and equity—cost of capital.

According to Chang et al. (2009), long-term debt is the most important proxy of capital structure, followed by short-term debt, and then convertible debt. Taboada (2011) studied the effect of changes in bank ownership structure on the allocation of capital based on some international evidence. Taboada (2011) provided some evidence that foreign presence could improve capital allocation efficiency by increasing lending to more productive industries, primarily in common law countries. Tongkong (2012) investigated key factors impacting capital structure decision and its speed of adjustment of Thai listed real estate companies. The results of the survey indicated that firm leverage was positively associated with median industry leverage. Furthermore, firm size and growth opportunities had positive relationship with firm leverage, whereas profitability and leverage were negatively related. The results supported pecking order theory as higher profitability firms tend to have less debt and corporations with higher growth opportunities tend to have bigger leverage. Additionally, the study also discovered that real estate companies partially adjust their capital structure towards the target level capital structure only at the rate of $63 \%$.

Kolasinski (2009) reported that subsidiaries were more likely to have their own external debt when they had fewer growth options and higher cash flow than the rest of the firm. Kesternich and Schnitzer (2010) investigated how multinational firms selected the capital structure of their foreign affiliated in response to political risk. They concentrated on two choice variables, the leverage and the ownership structure of the foreign affiliate and distinguished various kinds of political risk, such as 
expropriation, unreliable intellectual property rights and confiscatory taxation. In their theoretical analysis they found that, as political risk increases, the ownership share tends to decrease, whereas leverage could both increase or decrease, depending on the type of political risk.

Guney et al. (2011) analyzed the relationship between product market competition and the capital structure of Chinese listed firms in a static and dynamic setting. They studied an unbalanced panel dataset of 10,416 firm-year observations in 12 industries over the period 1994-2006. They reported that there were significant differences in the debt ratios and product market competition across various industries. They suggested that the relationship between leverage and product market competition was non-linear, depending on industry kind, company size and firms' growth opportunities. The system-GMM results revealed that Chinese firms tend to adjust their leverage ratios through time.

Khodaei Valahzaghard and Babaei dazghei (2012) presented an investigation to measure the effect of financial and macro economical factors on capital adequacy. They gathered the necessary information from financial statements and balance sheets of nine Iranian private banks over the period of 20052011. The results of analyzing the data based on the implementation of linear regression technique disclosed that there were some meaningful relationship between financial figures, including bank size and profitability, and capital adequacy. However, the survey did not indicate any relationship between macro economical factors, including growth domestic product and inflations, and capital adequacy.

\section{The proposed study}

The proposed study of this paper uses the financial information of 107 selected companies from 18 different industries listed on Tehran Stock Exchange over the period of 2004-2011 covering 40\% of total number of companies listed in this stock exchange. The proposed study examines the following seven hypotheses,

$\mathrm{H}_{1}$ : There is a positive relationship between effective tax rate and capital structure.

$\mathrm{H}_{2}$ : There is a positive relationship between firms' growth rate and capital structure.

$\mathrm{H}_{3}$ : There is a positive relationship between fixed assets and capital structure.

$\mathrm{H}_{4}$ : There is a positive relationship between firms' size and capital structure.

$\mathrm{H}_{5}$ : There is a positive relationship between operating risk and capital structure.

$\mathrm{H}_{6}$ : There is a negative relationship between profitability and capital structure.

$\mathrm{H}_{7}$ : There is a positive relationship between industry type and capital structure.

The proposed study of this paper uses regression analysis where capital structure (TDR) is dependent variable and effect tax rate (TAXR), firm's growth rate (GROR), fixed assets (FIX), firm size (SIZE), operating risk (OPR), profitability (PROR) and industry type (INDUS) are independent variables. The proposed study of this paper uses panel data for regression analysis and Table 1 shows basic statistical observations of the selected firms. 
Table 1

Descriptive Statistics

\begin{tabular}{|c|c|c|c|c|c|c|c|c|c|}
\hline \multirow{2}{*}{ Variable } & \multirow{2}{*}{$\begin{array}{c}\mathrm{N} \\
\text { Statistic }\end{array}$} & \multirow{2}{*}{$\begin{array}{l}\text { Minimum } \\
\text { Statistic }\end{array}$} & \multirow{2}{*}{$\begin{array}{l}\text { Maximum } \\
\text { Statistic }\end{array}$} & \multirow{2}{*}{$\begin{array}{c}\text { Mean } \\
\text { Statistic }\end{array}$} & \multirow{2}{*}{$\begin{array}{c}\text { Std. Deviation } \\
\text { Statistic }\end{array}$} & \multicolumn{2}{|c|}{ Skewness } & \multicolumn{2}{|c|}{ Kurtosis } \\
\hline & & & & & & Statistic & Std. Error & Statistic & Std. Error \\
\hline TDR & 856 & .00 & 1.14 & .6417 & .15929 & -.422 & .084 & .172 & .167 \\
\hline FIX & 856 & .00 & .94 & .2493 & .17788 & 1.045 & .084 & 1.028 & .167 \\
\hline GROR & 856 & -1.00 & 2.18 & .1853 & .33783 & 1.853 & .084 & 7.433 & .167 \\
\hline INDUS & 856 & 1.00 & 18.00 & 5.8224 & 4.38352 & .797 & .084 & -.259 & .167 \\
\hline OPR & 856 & .08 & 2.99 & .5206 & .33841 & 1.891 & .084 & 5.669 & .167 \\
\hline PROR & 856 & -.31 & 1.06 & .1757 & .14473 & 1.261 & .084 & 2.982 & .167 \\
\hline SIZE & 856 & 4.43 & 7.90 & 5.6824 & .60638 & .813 & .084 & .854 & .167 \\
\hline TAXR & 856 & .00 & .91 & .1258 & .08855 & .687 & .084 & 6.065 & .167 \\
\hline
\end{tabular}

Before we use regression analysis, we need to make sure that the data are normally distributed. The results of the implementation of Kolmogorev-Smirnov Test are summarized in Table 2 as follows,

\section{Table 2}

The results of One-Sample Kolmogorev-Smirnov Test

\begin{tabular}{|c|c|c|c|}
\hline & & TDR & Resid \\
\hline $\mathrm{N}$ & & 856 & 747 \\
\hline \multirow{2}{*}{ Normal Parameters } & Mean & 0.6417 & 0.0000 \\
\hline & Std. Deviation & 0.15929 & 0.11331 \\
\hline \multirow[t]{3}{*}{ Most Extreme Differences } & Absolute & 0.035 & 0.042 \\
\hline & Positive & 0.032 & 0.037 \\
\hline & Negative & -0.035 & -0.042 \\
\hline Kolmogorev-Smirnov Z & & 1.010 & 1.139 \\
\hline Asymp. Sig. (2-tailed) & & 0.259 & 0.149 \\
\hline
\end{tabular}

As we can observe from the results of Table 2, the level of significance for TDR and Resid are 0.259 and 0.149 , respectively and none of them is less than 0.05 . Therefore, we can conclude that they are normally distributed. We have also used Hausman Test to find out whether we should use fixed or variable method and the test examines the following hypothesis,

$\left\{\begin{array}{lc}H_{0}: & \text { Random effects } \\ H_{1}: & \text { Fixed effects }\end{array}\right.$

The Hausman test calculates the following ratio to perform the test,

$H=n \hat{q}^{\prime}(\operatorname{Avar}(\hat{q}))^{-1} \hat{q}$,

where $\hat{q}$ is the estimated difference for descriptive variables, Avar represents the variance of observations and $n$ is the number of observations. The results of Hausman test on cross-section random test yields Chi-Square value of 77.372047 with P-value of 0.0000 . Therefore, the null hypothesis is rejected and we can conclude that it is better to use fixed effect method for regression analysis. The proposed model of this paper uses the following regression model,

$\mathrm{TDR}=\beta_{0}+\beta_{1} \mathrm{FIX}_{\mathrm{it}}+\beta_{2} \mathrm{GROR}_{\mathrm{it}}+\beta_{3} \mathrm{SIZE}_{\mathrm{it}}+\beta_{4} \mathrm{OPR}_{\mathrm{it}}+\beta_{5} \mathrm{PROR}_{\mathrm{it}}+\beta_{6} \mathrm{TAXR}_{\mathrm{it}}$, 
where $\beta_{0}, \beta_{1}, \ldots, \beta_{6}$ are parameters of regression analysis and they are estimated based on the implementation of ordinary least square technique. We first present details of ANOVA test to verify whether the linear model is suitable or not and the details of our survey are summarized in Table 3.

Table 3

The results of ANOVA test

\begin{tabular}{lccccc}
\hline & Sum of Squares & Df & Mean Square & F & Sig. \\
\hline Regression & 5.687 & 6 & .948 & 50.272 & $.000^{\text {a }}$ \\
Residual & 16.007 & 849 & .019 & & \\
\hline Total & 21.694 & 855 & & & \\
\hline
\end{tabular}

The results of ANOVA test indicate that F-value is statistically meaningful, when the level of significance is five percent and we can conclude that the null hypothesis is rejected and there are some linear relationship between independent variable and dependent variables. Table 4 shows details of our survey on regression analysis using Panel EGLS (Cross-section weights).

Table 4

The summary of regression analysis using cross-section weights method

\begin{tabular}{ccccc}
\hline Parameters & Coefficient & Std. Error & t-Statistic & Prob. \\
\hline C & 1.030532 & 0.113732 & 9.061058 & 0.0000 \\
FIX & 0.025701 & 0.037628 & 0.683030 & 0.4948 \\
GROR & 0.014162 & 0.006216 & 2.278117 & 0.0231 \\
PROR & -0.456229 & 0.043406 & -10.51080 & 0.0000 \\
OPR & -0.000110 & 0.000343 & -0.320039 & 0.7490 \\
SIZE & -0.059617 & 0.019364 & -3.078791 & 0.0022 \\
TAXR & 0.132262 & 0.030809 & 4.292958 & 0.0000 \\
AR(1) & 0.380320 & 0.033241 & 11.44133 & 0.0000 \\
\hline
\end{tabular}

As we can observe from the results of Table 4, statistical t-student associated with GROR, PROR, SIZE and TAXR are statistically meaningful when the level of significant is five percent. However, tstudent values associated with FIX and OPR are not statistically meaningful when the level of significance is five percent. Table 5 shows details of other statistical observations associated with weighted and un-weighted statistics.

Table 5

The summary of statistical observations of weighted and un-weighted

\begin{tabular}{lllr}
\hline Weighted & & & \\
\hline R-squared & 0.881560 & Mean dependent var & 1.005814 \\
Adjusted R-squared & 0.860483 & S.D. dependent var & 0.676045 \\
S.E. of regression & 0.088994 & Sum squared resid & 5.029156 \\
F-statistic & 41.82625 & Durbin-Watson stat & 2.019079 \\
Prob(F-statistic) & 0.000000 & & \\
\hline Un-weighted & & & 0.639714 \\
\hline R-squared & 0.718552 & Mean dependent var & 1.949138 \\
\hline Sum squared resid & 5.435047 & Durbin-Watson stat
\end{tabular}

According to Table $5, \mathrm{R}^{2}$ is 0.88 for weighted and 0.72 for un-weighted regression models, which means the results can describe a significance portion of changes in dependent variable. In addition, Durbin-Watson ratios for weighted and un-weighted regression models are 2.019 and 1.949, which means there is not auto-correlation among residuals. 


\section{The results}

In this section, we present details of our findings to test seven hypotheses.

\subsection{The first hypothesis: Tax rate and Capital structure}

Based on the results of Table 4, we can observe that there is a positive and meaningful relationship between tax rate (TAXR) and capital structure when the level of significance is five percent. Therefore, the first hypothesis is confirmed. In other words, an increase of one unit on tax rate will increase capital structure by 0.132262 .

\subsection{The second hypothesis: firms' growth rate and capital structure}

Based on the results of Table 4, we can observe that there is a positive and meaningful relationship between firms' growth rate and capital structure when the level of significance is second percent. Therefore, the first hypothesis is confirmed. In other words, an increase of one unit on tax rate will increase capital structure by 0.01416 .

\subsection{The third hypothesis: fixed assets and capital structure}

Based on the results of Table 4, we can observe that there is no meaningful relationship between firms' fixed assets and capital structure when the level of significance is five percent. Therefore, the third hypothesis is rejected and there is no evidence to believe that there is any relationship between fixed assets and capital structure.

\subsection{The fourth hypothesis: firm's size and capital structure}

Based on the results of Table 4, we can observe that there is a meaningful relationship between firms' size and capital structure when the level of significance is five percent. However, the negative sign of t-student implies that the relationship is not positive. Therefore, the fourth hypothesis is rejected and there is a negative relationship between firm's size and capital structure.

\subsection{The fifth hypothesis: operating risk and capital structure}

Based on the results of Table 4, we can observe that there is no meaningful relationship between firms' operating risk and capital structure when the level of significance is five percent. Therefore, the fifth hypothesis is rejected and there is no evidence to believe that there is any relationship between operating risk and capital structure.

\subsection{The sixth hypothesis: firm's profitability and capital structure}

Based on the results of Table 4, we can observe that there is a meaningful relationship between firms' size and capital structure when the level of significance is five percent. The negative sign of t-student means that the relationship is consistent with what we expected. Therefore, the sixth hypothesis is confirmed and we conclude that there is a negative relationship between firm's profitability and capital structure.

\subsection{The seventh hypothesis: the effects of sector on capital structure}

The last issue is associated with the effects of industry on capital structure and we use analysis of variance to investigate this issue among 18 different industries. The null hypothesis of this survey is as follows, 
$\mathrm{H}_{0}: \mu_{1}=\mu_{2}=\mu_{3}=\ldots=\mu_{18}$

$\mathrm{H}_{1}$ : At least two sectors of industry have different mean in profitability.

Table 6 shows details of our ANOVA test.

Table 6

The results of ANOVA test

\begin{tabular}{lccccc}
\hline TDR & Sum of Squares & df & Mean Square & F & Sig. \\
\hline Between Groups & .600 & 17 & .035 & 1.401 & .128 \\
Within Groups & 21.095 & 838 & .025 & & \\
\hline Total & 21.694 & 855 & & & \\
\hline
\end{tabular}

Based on the results of Table 6, F-value is not statistically meaningful when the level of significance is five or even ten percent. Therefore, we can conclude that there is no significance difference between the mean of profitability among various sectors of industry.

\section{Conclusion}

In this paper, we have presented an empirical investigation to study the impact of seven factors on capital structure using the panel data gathered from Tehran Stock Exchange over the period of 20042011. The proposed study has used regression analysis and found that there was a positive relationship between tax rate and firm's growth rate, and capital structure. The result of the survey also has indicated that there was a negative relationship between firm's profitability and capital structure. However, there was no evidence to believe that there was any relationship between fixed assets and capital structure. We have also concluded that there was a negative relationship between firm's profitability and capital structure but the results of our survey did not indicate that there was any difference between the mean of profitability in various sectors.

\section{Acknowledgment}

The authors would like to thank the officials of Tehran Stock Exchange for providing the necessary information requested in this paper.

\section{References}

Azouzi, M.A., \& Anis, J. (2012). CEO emotional bias and investment decision, Bayesian network method. Management Science Letters, 2(4), 1259-1278.

Chang, C., Lee, A.C., \& Lee, C.F. (2009). Determinants of capital structure choice: A structural equation modeling approach. The Quarterly Review of Economics and Finance, 49(2), 197-213.

de Jong, A., Kabir, R., \& Nguyen, T.T. (2008). Capital structure around the world: The roles of firmand country-specific determinants. Journal of Banking \& Finance, 32(9), 1954-1969.

Delcoure, N. (2007). The determinants of capital structure in transitional economies. International Review of Economics \& Finance, 16(3), 400-415.

Guney, Y., Li, L., Fairchild, R. (2011). The relationship between product market competition and capital structure in Chinese listed firms. International Review of Financial Analysis, 20(1), 41-51

Kolasinski, A.C. (2009).Subsidiary debt, capital structure and internal capital markets. Journal of Financial Economics, 94(2), 327-343.

Kesternich, I., \& Schnitzer, M. (2010). Who is afraid of political risk? Multinational firms and their choice of capital structure. Journal of International Economics, 82(2), 208-218. 
Khodaei Valahzaghard, M., \& Babaei dazghei, M. (2012). An empirical study to measure the impact of financial and macro economical figures on capital adequacy. Management Science Letters, 2(8), 2833-2838.

Lahmiri, S. (2012). Resilient back-propagation algorithm, technical analysis and the predictability of time series in the financial industry. Decision Science Letters, 1(2), 47-52.

Singh, M., \& Nejadmalayeri, A. (2004). Internationalization, capital structure, and cost of capital: evidence from French corporations. Journal of Multinational Financial Management, 14(2), 153169.

Taboada, A. G. (2011).The impact of changes in bank ownership structure on the allocation of capital: International evidence. Journal of Banking \& Finance, 35(10), 2528-2543.

Tongkong, S. (2012).Key factors influencing capital structure decision and its speed of adjustment of Thai listed real estate companies. Procedia - Social and Behavioral Sciences, 40, 716-720 